Original research article

\title{
Difference in determination of cognitive deficit by MMSE and MoCA methods in elderly long-term care
}

\author{
Silvia Puteková, Ol'ga Kabátová *, Andrea Botíková, Jana Martinková \\ Trnava University, Faculty of Health and Social Work, Department of Nursing, Trnava, Slovak Republic
}

\begin{abstract}
Objective: The aim of the research was to determine the influence of selected determinants on the level of cognitive functions in seniors in long-term care and to verify the difference in the determination of cognitive deficits by MMSE and MoCA methods.

Design: The work has the design of a cross-sectional quantitative study conducted on the basis of a questionnaire survey.

Methods: The population surveyed consisted of 792 residents of long-term care facilities who were included in the sample on a deliberate basis. Quantitative research was conducted using two psychometric tests of MMSE and MoCA. The influence of selected determinants affecting the level of cognitive functions and the difference in cognitive deficit determination were verified by statistical tests: Pearson's chi-square test, Kruskal-Wallis test, Pearson and Spearman's correlation coefficient.

Results: The results showed a statistically significant relationship between age (in men $\rho=-0.244$; Sig. $<0.01$ ) and length of education ( $\rho=0.164)$ and MMSE test results. In the MMSE test, it was also shown that males have a higher incidence of cognitive impairment than women and that more women than men fall into the normal range. The relationship between the results of the MoCA test and the selected variables was not confirmed. The results clearly demonstrated that there is a difference in determining the cognitive deficit between MMSE and MoCA.

Conclusions: The research results point to the need to assess cognitive functions and to diagnose their disorders in seniors living in longterm care facilities, especially with reference to the selection of a suitable psychometric tool.
\end{abstract}

Keywords: Cognitive deficit; Long-term care; MMSE; MoCA; Senior

\section{Introduction}

Cognition is a complex group of mental processes that includes memory, attention, language and decision making, and its slight deterioration may be an early sign of the disease that leads to dementia. Dementia is a severe mental disorder caused by an organic disease or brain damage. The most characteristic indicator of dementia is a disorder of cognitive functions that leads to social disability and limits people in performing basic daily activities. Dementia is therefore not only a health problem, but also an economic and social one (Kalvach et al., 2008). Although dementia is not part of aging, it is most common in older people (Holmerová et al., 2007). According to some findings, the probability of dementia in old age is up to 15-20\% (Ondášiová, 2011). Based on WHO and Alzheimer Disease International data from 2012, the number of people with dementia is currently estimated at 38 million. There is a prognosis which claims that this figure will double by 2030 and possibly triple by 2050 (Czech Alzheimer Society, 2012; WHO, 2012). The prevalence of dementia in long-term care facilities is estimated to be up to $80 \%$ (Mitchell et al., 2004; Moss et al., 2002). Early diagnosis of this disease can detect people at risk of complications (Ashford et al., 2006). Many studies (Freund,
2006; Lin et al., 2013) found that health workers are usually absent in the diagnosis of cognitive disorders or dementia, with the prevalence of the missed diagnosis ranging from $25 \%$ to $90 \%$. Primary care physicians may not recognize cognitive impairment to a mild and severe stage (Iliffe et al., 2003). Brunovsky et al. (2003) report that, according to some estimates, $75 \%$ of patients with moderate cognitive impairment and over $95 \%$ of patients with mild cognitive impairment miss the attention and diagnosis in primary health care. Evaluation of cognitive level is clearly the basis for early detection and initial treatment of cognitive impairment (Shekelle et al., 2001). Screening tests are quick and useful tools for assessing the cognitive status of patients. In particular, they provide information on the overall state of cognitive functions without neuropsychological examination. On average, these tests take only several minutes to be completed and in many cases they are used for various types of research (Lezak et al., 2004). However, it is important to emphasize that the tests are a source of valuable but still only partial information. When assessing cognitive impairment in seniors, it is necessary to use the latest scientific knowledge, and knowledge of the risks and complications of their misidentification. An educated nurse thus prevents subsequent or permanent damage to the senior (Pokorná et al., 2013).

\footnotetext{
* Author for correspondence: Ol'ga Kabátová, Trnava University, Faculty of Health and Social Work, Department of Nursing, Univerzitné nám. 1, 91743 Trnava, Slovak Republic; e-mail: olga.kabatova@truni.sk http://doi.org/10.32725/kont.2019.024

Submitted: 2018-07-31 • Accepted: 2019-03-19 • Prepublished online: 2019-04-17 


\section{Goal}

The aim of the research was to determine the influence of selected determinants on the level of cognitive functions in seniors in long-term care and to verify the difference in the determination of cognitive deficits by MMSE and MoCA.

\section{Materials and methods}

For this research, a design of a cross-sectional quantitative study based on a questionnaire survey was selected.

The choice of respondents was deliberate. Psychometric testing was performed only for clients with a selection criterion: consent to research realization and collaboration ability, the ability to speak, and fine motor skills, vision and hearing. The sample was made up of seniors in nursing homes and facilities for seniors in the Trnava region. The selected set of respondents was representative because it reflected all of the monitored features of the basic set. A total of 792 respondents were surveyed, of which $64 \%$ were women and $36 \%$ were men. In terms of age, $7 \%$ of respondents were part of the "up to 60 -year-olds" study category, $15 \%$ were $61-70$ year-olds, $34 \%$ were $71-80$ year-olds, $36 \%$ were $81-90$, and the oldest age category - 91 year-olds and over - included $8 \%$ of respondents. In terms of the number of years of education, the majority of respondents reported $10-12$ years (55\%), almost one third of the participants' education took $13-18$ years (31\%), $8 \%$ were educated in 9 years, and 6\% studied for more than 19 years.

Data collection ran from March 2017 to September 2017. Before the administration itself, participants and staff were informed of the ongoing research. Psychometric testing was conducted by the study authors in collaboration with senior nurses of the facilities. Despite the fact that the set of respondents was not evenly distributed, the groups were statistically comparable. Data collection was performed using two methods - Mini Mental State Examination (MMSE) and Montreal Cognitive Test (MoCA). MoCA is a highly specific and sensitive test that is able to distinguish "age-related cognitive decline" and mild cognitive impairment or light dementia (Nasreddine et al., 2005). It is suitable for detecting the early stages of dementia. In the test, which consisted of 13 items with scores in a standardized form, we assessed various modalities: ability, spatial orientation, visual constructive skill, animal naming, memory, attention, repetition of letters, subtraction, repetition of sentences, word processing, abstraction, word-finding skill. The maximum rating is 30 points. In the range of 30-26 points, we refer to physiological findings, less than 26 points indicates the beginnings of Alzheimer's disease (Reban, 2006).
The MoCA test detects an MCI (mild cognitive impairment) within a $90-96 \%$ sensitivity range with a specificity of $87 \%$ and 95\% confidence interval. Administering the test takes about 10 minutes. MMSE serves for a simple global assessment of the mental state. It is the most widely used screening test of cognitive functions (Vyhnálek et al., 2011). It was originally developed as a supportive method for differential diagnosis to distinguish patients with any dementia. The test was proven to be the most accurate in assessing Alzheimer's disease (Hort et al., 2007). Completion of the test is not time-limited. Administration usually lasts 5-10 minutes. The maximum achievable score is 30 points (Lezak et al., 2004). The MMSE test is relatively reliable, it has a good specificity for the diagnosis of dementia in general (96\% for the 24-point limit) and good use in monitoring the progress of the disease (Kalvach et al., 2008; Topink and Neurwith, 1995). The data obtained was saved and included in a database created using Microsoft Office Word and Excel. In the analysis and processing of data we used methods of descriptive and inductive statistics, from which we used Pearson's chi-square test, Kruskal-Wallis test, Pearson's and Spearman's correlation coefficient. The results of the research were processed using SPSS 16.0.

\section{Results}

\section{The relationship between age and length of education and the results of cognitive functions tests}

To verify the relationship, we used statistical testing of the relationship between cardinal variables. We chose a non-parametric test criterion. The results of the Spearman's correlation coefficient of age, length of education and MMSE scores are shown in the first section of Table 1 , where we can see the coefficient $\rho=0.164$ (Sig. < 0.01) representing the weak positive linear relationship between the length of education and the MMSE test result. There was no significant relationship between the age of the respondents and the MMSE test result (Sig. > 0.05). However, in the part of MMSE results we can see a significant negative relationship between age and MMSE score in men $(\rho=-0.244$; Sig. $<0.01)$ and between the length of education and MMSE scores in women $(\rho=0.207$; Sig. < 01). In the case of men with increasing age, MMSE scores are slightly lower and the relationship between the length of education and MMSE in women is weak, too. But there is a positive correlation here, which can be interpreted like this: the longer the education in women, the slightly higher the MMSE score.

Table 1. The relationship between age, length of education and MMSE score $(n=792)$

\begin{tabular}{llcccccc} 
& & \multicolumn{2}{c}{ Whole set } & \multicolumn{2}{c}{ Men } & \multicolumn{2}{c}{ Women } \\
\cline { 3 - 7 } & & age & education & age & education & age & education \\
\hline \multirow{2}{*}{ MMSE } & Spearman's $\rho$ & -0.068 & 0.164 & -0.244 & 0.12 & 0.027 & 0.207 \\
& Sig. & 0.180 & 0.001 & 0.003 & 0.155 & 0.675 & 0.001 \\
& $N$ & 792 & 792 & 285 & 285 & 507 & 507 \\
\hline
\end{tabular}

Table 2 shows the results of the relationship between age, length of education and MoCA scores. We have not noticed any significant correlation relationships within this test
(Sig. > 0.05). In case of evaluation in men and women subgroups between age, education and MoCA scores, significant relationships were not found (Sig. > 0.05). 
Table 2. The relationship between age, length of education and MoCA score $(n=792)$

\begin{tabular}{llcccccc} 
& & \multicolumn{2}{c}{ Whole set } & \multicolumn{2}{c}{ Men } & \multicolumn{2}{c}{ Women } \\
\cline { 3 - 8 } & & age & education & age & education & age & education \\
\hline \multirow{2}{*}{ MoCA } & Spearman's $\rho$ & 0.074 & -0.049 & -0.003 & -0.062 & 0.115 & -0.041 \\
& Sig. & 0.139 & 0.327 & 0.975 & 0.462 & 0.067 & 0.519 \\
& $N$ & 792 & 792 & 285 & 285 & 507 & 507 \\
\hline
\end{tabular}

\section{The relationship between gender and the results of cognitive function tests}

Firstly, we tried to determine the relationship by testing the difference in MMSE and MoCA scores between men and wom- en by Mann-Whitney $U$ test. The results are shown in Table 3. According to what we discovered, we note that differences in MMSE and MoCA scores between men and women are not significant.

Table 3. The relationship between sex and MMSE and MoCA score $(n=792)$

\begin{tabular}{|c|c|c|c|c|c|}
\hline & Sex & $N$ & Average order & \multicolumn{2}{|c|}{ Mann-Whitney's test } \\
\hline \multirow[t]{3}{*}{ MMSE } & men & 285 & 375.22 & $U$ & 16103 \\
\hline & women & 507 & 408.18 & $Z$ & -1.641 \\
\hline & total & 792 & & Sig. & 0.101 \\
\hline \multirow[t]{3}{*}{ MoCA } & men & 285 & 375.33 & $U$ & 16627 \\
\hline & women & 507 & 408.18 & $Z$ & -1.34 \\
\hline & total & 792 & & Sig. & 0.180 \\
\hline
\end{tabular}

In the second step, we went through an alternative difference test where we compared the categorized variable MMSE degree. As a test criterion we used the Chi-square Independence Test, which compares the multiplicity of representation of individual categories in multiple groups with the expected rates shown in the cells of Cross-Table 4 . The test result is given at the bottom of the table with the Sig value $<0.05$, which indicates a significant difference. When looking at individual cells in the rows for men and women, we see a higher incidence of cognitive impairment in men (10.50\%), whereas for women this category is represented by a lower amount (3.20\%). On the other hand, a few more women $(60.60 \%)$ than men $(53.80 \%)$ fall into the normal range. In mild and moderate grades, the differences in relative rate are not significant (Chart 1$)$.

Table 4. Alternative testing of the relationship between sex and MMSE score $(n=792)$

\begin{tabular}{|c|c|c|c|c|c|c|}
\hline & & & & & & \\
\hline & & norm & mild & moderate & severe & Total \\
\hline Men & N & 153 & 64 & 38 & 30 & 285 \\
\hline & expected $N$ & 165.4 & 61.2 & 41.6 & 16.8 & 285 \\
\hline & $\%$ & $53.80 \%$ & $22.40 \%$ & $13.30 \%$ & $10.50 \%$ & $100.00 \%$ \\
\hline Women & N & 304 & 106 & 78 & 19 & 507 \\
\hline & expected $N$ & 291.6 & 108.8 & 74.4 & 32.2 & 507 \\
\hline & $\%$ & $60.60 \%$ & $20.90 \%$ & $15.30 \%$ & $3.20 \%$ & $100.00 \%$ \\
\hline & Rate & df & Sig. & & & \\
\hline Chi-square & 9.257 & 3 & 0.026 & & & \\
\hline
\end{tabular}

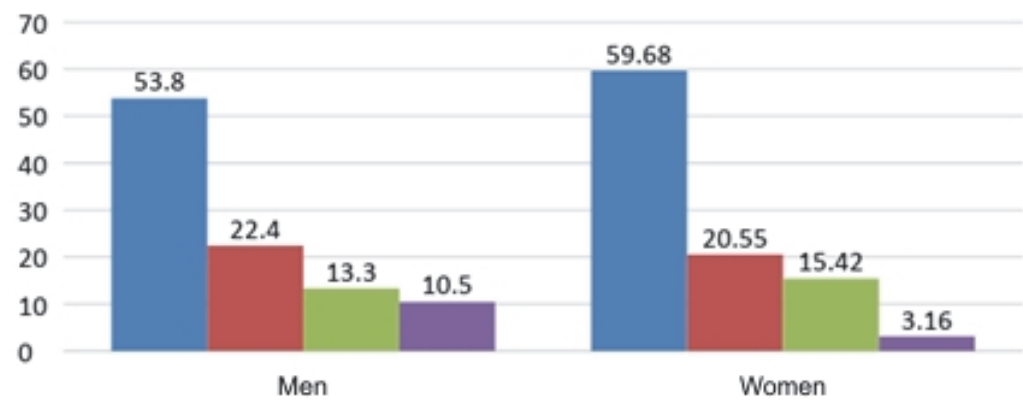

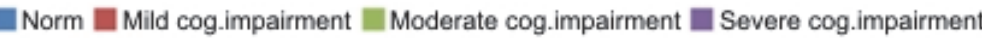

Chart 1. Relative rates representation of cognitive deficit grades according to MMSE in men and women 
The same test criterion was used to compare the categorized MoCA variable between males and females. The results are shown in Table 5, where at the bottom we can see the chi-square result of the Sig. test > 0.05. The differences in the cross-table among individual cells are not significant, so the difference between men and women in the categorized variable MoCA grade is interpreted as insignificant. A graphical representation of variance in the rate is shown in Chart 2.

\begin{tabular}{|c|c|c|c|c|}
\hline \multicolumn{5}{|c|}{$\begin{array}{l}\text { Table 5. Alternative testing of the relatio } \\
\text { and MoCA score }(\boldsymbol{n}=\mathbf{7 9 2}) \\
\text { MoCA grades }\end{array}$} \\
\hline & & norm & deficit & Total \\
\hline Men & $\begin{array}{c}N \\
\text { Expected } N \\
\%\end{array}$ & $\begin{array}{c}10 \\
14.2 \\
3.50 \%\end{array}$ & $\begin{array}{c}275 \\
270.8 \\
96.50 \%\end{array}$ & $\begin{array}{c}285 \\
295 \\
100.00 \%\end{array}$ \\
\hline Women & $\begin{array}{c}N \\
\text { Expected } N \\
\%\end{array}$ & $\begin{array}{c}38 \\
30.6 \\
7.50 \%\end{array}$ & $\begin{array}{c}469 \\
476.4 \\
93.90 \%\end{array}$ & $\begin{array}{c}507 \\
507 \\
100.00 \%\end{array}$ \\
\hline \multicolumn{2}{|c|}{ Chi-square } & $\begin{array}{l}\text { Rate } \\
2.585\end{array}$ & $\begin{array}{c}\mathrm{df} \\
1\end{array}$ & $\begin{array}{l}\text { Sig. } \\
0.108\end{array}$ \\
\hline
\end{tabular}

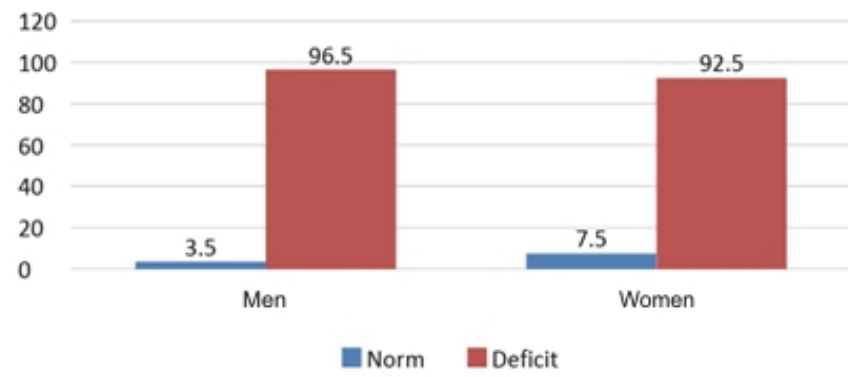

Chart 2. Relative rates representation of cognitive deficit grades according to MoCA in men and women

\section{The difference in determining the cognitive deficit between MMSE and MoCA}

To verify the difference, we have recoded the MMSE degrees to the dichotomous variables ( 1 = norm; 2 = deficit) according to the standard so that it is equated to the MoCA degree. We applied a sign test to find out the differences in the value of the associated category. The result in Table 6 shows a significant difference in the occurrence of positive, negative differences and the same values (Sig. < 0.001) that represent the screening result of the test (norm/deficit). We can see that in 430 cases, the MoCA test has identified a deficiency and MMSE test has identified a norm, in 10 cases it is the opposite - when MMSE assigned the patient to the fault band and the MoCA test to the normal band. In 352 cases, banding was the same for both tests.

Table 6. The difference of deficit determination between MMSE and MoCA $(n=792)$

\begin{tabular}{lcccc} 
& & \multicolumn{2}{c}{ Sign test } \\
\hline MoCA - MMSE & negative differences & 10 & $Z$ & -14.155 \\
(norm = 1; & positive differences & 430 & Sig. & 0.000 \\
deficit = 2) & equal & 352 & & \\
& total & 792 & & \\
\hline
\end{tabular}

In Table 7 we specify the result by adding relative rates. We can see that in $54.45 \%$ of cases, the MoCA test determined the deficiency and the MMSE test determined the norm, in $1.02 \%$ of cases it is the opposite - MMSE assigned the patient to the fault band and the MoCA test to the normal band. In 352 cases, the bandwidth was the same for both tests, of which $39.4 \%$ were included in the deficit band by both tests and $5.09 \%$ of the respondents were in the norm.

\begin{tabular}{lr}
$\begin{array}{l}\text { Table 7. 4-categories relative rates of screening differences } \\
\text { between MMSE and MoCA tests }\end{array}$ & $\%$ \\
\hline & 1.02 \\
\hline MoCA norm - MMSE deficit (negative differences) & 54.45 \\
MoCA deficit - MMSE norm (positive differences) & 39.44 \\
MoCA deficit - MMSE deficit (equal) & 5.09 \\
MoCA norm - MMSE norm (equal) & 100.00 \\
\hline
\end{tabular}

\section{Discussion}

Assessing the level of cognitive functions is a fundamental element of an effective senior assessment. Age is a risk factor for many disorders, including those related to the loss of cognitive functions (Pokorná et al., 2013). With increasing age, plasticity of thinking is reduced, and word-finding skills and psychomotor pace slow down. The accumulation of adverse lifestyle factors such as loneliness, loss of a partner, change of economic conditions, housing, somatic diseases and others also occur. Changes in cognitive functions significantly determine important areas of a senior's life, the quality of his/her life and also the quality of life of people who take care of him/ her. A sensitive indicator of changes in seniors' cognition is their level of self-sufficiency, which, among other factors, is significantly influenced by functional capacity in the field of cognitive functions necessary for planning, management and actual implementation of daily life activities (Kalvach et al., 2004). One of the most eminent cognitive disorders in seniors is dementia. Dementia is a syndrome that arises from a brain disease. There is a disruption of the higher cortical functions, including memory, thinking, orientation, speech, learning and judgment, with consciousness not obscured. The deterioration of these functions is accompanied by a deterioration in the control of emotions, social behavior or motivation (Smolík, 1996). In general, it can be assumed that dementia is caused by a combination of multiple influences of various risk factors. The identification of these risk factors is important in terms of the possibility of modifying the lifestyle. Significant risk factors for dementia are higher age, female gender, genetics, low level of education, recurrent head trauma, hypertension, hyperlipidemia, diabetes mellitus, smoking and unhealthy lifestyle (Szaboó, 2006; Turčáni, 2001). Protective factors, on the other hand, are higher education, higher psychological activity, mental training, use of anti-inflammatory drugs, hormonal substitution in women after menopause, early and effective treatment of depression and non-declining psychological activity in elderly age (Neuroimmunological Center for Alzheimer's Disease, 2008). Early recognition of dementia, its distinction from other disorders and finding its causes is not always easy. MMSE or MoCA psychometric scales are very helpful in 
the initial diagnosis and quantification of severity (Burns et al., 1999).

In our study, we have chosen a nonparametric test criterion for verifying the cardinal variables - age and the length of education in relation to the results of cognitive functions tests. The Spearman's coefficient of ordinal correlation test showed a coefficient $\rho=0.164$ (Sig. $<0.01$ ) representing the weak positive linear relationship between the length of education and the result of the MMSE test. There was no significant relationship between the age of the patients and the MMSE test result (Sig. > 0.05). However, we detected a significant negative relationship between age and the male MMSE score $(\rho=-0.244$; Sig. < 0.01) and between study duration and MMSE scores in females $(\rho=0.207$; Sig. < 0.01). According to our results, the score in MMSE test drops slightly in men with increasing age. Regarding women, the relationship between the length of education and MMSE is equally weak. This means that the higher education women have, the slightly higher the MMSE score is.

In the next survey, we verified the relationship between age, length of education and MoCA score. As a part of this test, we did not record any significant correlation relationships. On the contrary, the authors Siqueira et al. (2018) recommend setting limits on the MoCa testing based on years of school attendance. Studies on risk factors associated with dementia are mainly focused on Alzheimer's dementia (AD), as it is the most common cause of dementia. Age is the most well-known risk factor for dementia. Studies of prevalence and incidence of dementia and AD by Fratiglioni et al. (2000); Miech et al. (2002) have consistently shown an almost exponential increase with increasing age, because estimates of prevalence and incidence double with each five-year increase in age. In addition, women have been repeatedly shown to be associated with an increased risk of $\mathrm{AD}$, especially in old age. Our findings coincide with the interpreted results of Lezak et al. (2004) and other normative studies (Franco-Marina et al., 2015; Khan and Alkon, 2015; Spencer et al., 2013; Spering et al., 2012) which interpret the relationship between age and education and the results of MMSE test. However, many authors such as Lam et al. (2013), Cumming et al. (2013), Nasreddine et al. (2005), warn in their publications that these contexts should be taken into account, especially when interpreting the results of patients with extreme age values. In their studies, Smith and Bondi (2013), Mauk (2013) also show that these tests depend on the age and length of the senior's education.

The relationship between sex and the results of cognitive functions tests was first detected by testing the difference in MMSE and MoCA scores between males and females. Based on the findings, we noted that differences in MMSE scores and the MoCA test between men and women are not significant. In the second step, we therefore proceeded to alternative difference testing, where we compared the categorized variable of MMSE grades. We found that the representation of severe cognitive function impairment was higher (than expected) in men (10.50\%), while in women, this category was represented in a lower (than expected) amount (3.20\%). On the other hand, a few more women $(60.60 \%)$ than men $(53.80 \%)$ fell into the normal range. In mild and moderate grades, the differences in relative rates were not significant. Reban (2006) states that cognitive disorders have their risk factors and, if we prevent them, we can delay the cognitive function impairment. These risk factors also include a higher prevalence of cognitive impairment in women. This is confirmed by Davis et al. (2015) who present that age and femininity is a significant predictor of cognitive impairment. Studies by Mielke et al. (2014) and Gao et al. (1998) suggest that it is unclear whether women at this age have a higher risk of dementia or $\mathrm{AD}$ than men. However, several European studies suggest that women have a higher incidence of dementia or AD than men. Studies in the United States conducted by Mielke et al. (2014) did not show the difference or the difference differed with the age. Regardless of this difference in risk (in the number of occurrences) on the continents, all studies have consistently shown that more women than men suffer from $\mathrm{AD}$ at a specific age, probably because of the fact that women live longer (Mangialasche et al., 2012; Solomon et al., 2013). This higher number of affected women may not be true for other types of dementia, such as vascular dementia or dementia with Lewy's corpuscles. Mielke et al. (2014) also state that gender is an important variable to be taken into account when designing and analysing basic and clinical research. In many studies, gender refers to biological differences such as chromosomes (XX vs. XY), gonadal or hormonal differences. However, gender also refers to psychosocial and cultural differences between men and women, such as access to education and occupation. For example, at the beginning of this century, men had higher education, but at present, on average, women reach higher education than men. Both of these factors play an important role in the development and progression of dementia and can affect its prevalence and incidence among men and women. Understanding these differences helps define the individualization of treatment and preventive procedures for dementia. When verifying the difference in determining the cognitive deficit between the MMSE and the MoCA methods, we concluded that of a total of 792 respondents, 352 were included in the same bands in both tests. In contrast, in 430 cases, the MoCA test identified a deficiency and the MMSE test identified the norm. In 10 cases the MMSE assigned the patient to the disorder band and the MoCA test to the normal range. MMSE is therefore relatively sensitive in susceptibility to moderate to severe dementia but is very weak in screening for patients with mild cognitive impairment (MCI).

A study by Pinto et al. (2018) confirmed that the MoCA screening tool is better than MMSE for identifying MCI, and both tests were found to be correct for $\mathrm{AD}$ detection. In a study comparing MMSE with MoCA, the authors Nasreddine et al. (2005) had an MMSE sensitivity of only $18 \%$ for MCI detection, meaning that $82 \%$ of MCI subjects were not detected, while the MoCA test detected $90 \%$ of subjects with MCI. The high sensitivity of MoCA comes at a price of somewhat lower specificity - a false positivity. In the study, for example, the MCI specification was $87 \%$, meaning that $13 \%$ of people without a cognitive impairment were falsely labeled as damaged. The positive side of the MoCA is that the test itself and detailed instructions for its administration are available in several languages free of charge at www.mocatest.org. We believe that the MoCA test should become the first choice test for relatively highly performing patients with mild cognitive impairment.

\section{Limitations}

We see the limitations of our research in an unevenly distributed set of respondents. Therefore, its results cannot be generalized to the entire population of seniors living in long-term care facilities.

\section{Conclusions}

The use of evaluation and measurement techniques has been a part of standards of nursing care in recent years. Performing admission and also re-evaluating cognitive functions is neces- 
sary because the client of an institutional facility is clearly a member of so-called fragile people and is highly prone to any changes in his or her immediate vicinity. Our study showed that there is a difference in determining the deficit between MMSE and MoCA method and we can state that the MMSE test is suitable for rapid orientation in dementia detection and for the correct detection of moderate dementia from healthy aging, but its outcome is influenced by education and age. The MoCA test is suitable for early identification of cognitive impairment, it also evaluates executive functions, and when assessing the results, we take into consideration the number of years of completed education. It detects mild cognitive impairment (MCI) in 90-96\%, it is highly effective in diagnosing Alzheimer's dementia, but it is only used in people with $\mathrm{MCI}$ and non-serious cognitive impairment. In assessing cognitive deficits, we recommend focusing on at risk seniors - these being female and seniors of a higher age, taking into account the selection of an appropriate assessment tool. Assessing the cognitive functions of seniors in long-term care facilities is al- ways necessary at the admission to the facility, before a major change in treatment, and in the incidence of behavior that is unusual for an individual senior. It is recommended to develop a cognitive assessment plan, which should include: cognitive evaluation timetable, action plan for detecting the deficiency (cooperation with patient, relatives, staff and other specialists, procurement of individual care), assessment of the cognitive impairment plan (environmental assessment, assessment of the level of expertise of the staff and evaluation of the implementation of appropriate follow-up measures), and evaluation of the personnel management process (quality of care provided, diligent documentation, training of attending staff, supervision).

\section{Ethical aspects and conflict of interest}

The authors declare that the study has no conflict of interest, and the ethical aspects of research have been adhered to in its processing.

\section{Rozdiel v určení kognitívneho deficitu metódami MMSE a MoCA u seniorov v dlhodobej starostlivosti}

\section{Súhrn}

Ciel': Ciel'om výskumu bolo zistit' vplyv vybraných determinantov na úroveň kognitívnych funkcií u seniorov v dlhodobej starostlivosti a overit' rozdiel v určení kognitívneho deficitu metódami MMSE a MoCA.

Dizajn: Práca má dizajn prierezovej kvantitatívnej štúdie vykonanej na základe dotazníkového šetrenia.

Metodika: Výskumný súbor tvorilo 792 obyvatel'ov zariadení dlhodobej starostlivosti, ktorí boli do vzorky zaradení na základe zámerného výberu. Kvantitatívny výskum bol realizovaný pomocou dvoch psychometrických testov MMSE a MoCA. Vplyv vybraných determinantov ovplyvňujúcich úroveň kognitívnych funkcií a rozdiel v určení kognitívneho deficitu boli overované na základe štatistických testov: Pearsonov chí-kvadrát test, Kruskal-Wallisov test, Pearsonov a Spearmanov korelačný koeficient. Výsledky: Výsledky preukázali štatisticky významný vztah medzi vekom (u mužov $\rho=-0,244$; Sig. $<0,01$ ) a dížkou vzdelávania $(\rho=0,164)$ a výsledkami testu MMSE. Pri teste MMSE bolo tiež preukázané, že u mužov sa nachádza vyššie zastúpenie tažkého stupňa poruchy kognitívnych funkcií ako u žien a viac žien než mužov spadá do normálneho pásma. Vztah medzi výsledkami testu MoCA a vybranými premennými potvrdený nebol. Výsledky jednoznačne preukázali, že existuje rozdiel v určení kognitívneho deficitu medzi metódou MMSE a MoCA.

Záver: Výsledky výskumu poukazujú na potrebu posudzovania kognitívnych funkcií a skríningu ich porúch u seniorov žijúcich v zariadeniach dlhodobej ústavnej starostlivosti so zretel'om na výber vhodného psychometrického nástroja.

Kl'účové slová: dlhodobá starostlivost'; kognitívny deficit; MMSE; MoCA; senior

\section{References}

1. Ashford JW, Borson S, O'Hara R, Dash P, Frank L, Robert P, et al. (2006). Should older adults be screened for dementia? Alzheimers Dement 2(2): 76-85. DOI: 10.1016/j. jalz.2007.03.005.

2. Brunovsky M, Matousek M, Edman A, Cervena K, Krajca $\mathrm{V}$ (2003). Objective assessment of the degree of dementia by means of EEG. Neuropsychobiology 48(1): 19-26. DOI: $10.1159 / 000071824$.

3. Burns A, Craig S, Lawlor B (1999). Assessment scales in old age psychiatry. London: Martin Dunitz, $302 \mathrm{p}$.

4. Cumming TB, Churilov L, Linden T, Bernhardt J (2013). Montreal Cognitive Assessment and Mini-Mental State Examination are both valid cognitive tools in stroke. Acta Neurol Scand 128(2): 122-129. DOI: 10.1111/ane.12084.

5. Česká alzheimerovská společnost (2012). Světová zpráva o Alzheimerově chorobě 2012. [online] [cit. 2018-0614]. Available from: http://www.alzheimer.cz/clanky/ alzheimerova-choroba-ve-svete/svetova-zprava-o-alzheimerovechorobe-2012/
6. Davis RD, Gallien GJ, Moody KM, LeBlanc NR, Smoak PR, Bellar D (2015). Cognitive function and salivary dhea levels in physically active elderly African American women. Int J Endocrinol 2015: ID 219047.

7. Franco-Marina F, García-González JJ, Wagner-Echeagaray F, Gallo J, Ugalde O, Sánchez-García S, et al. (2010). The Minimental state examination revisited: Ceiling and floor effects a fterscore adjustment for education allevel in an aging Mexican population. Int Psychogeriatr 22(1): 72-81. DOI: 10.1017/ S1041610209990822.

8. Fratiglioni L, Launer LJ, Andersen K, Breteler MM, Copeland JR, Dartigues JF, et al. (2000). Incidence of dementia and major subtypes in Europe: a collaborative study of population-based cohorts. Neurologic diseases in the elderly research group. Neurology 54(11 Suppl. 5): S10-S15.

9. Freund B (2006). Office-based evaluation of the older driver. J Am Geriatr Soc 54(12): 1943-1944. DOI: 10.1111/j.15325415.2006.00966.x.

10. Gao S, Hendrie HC, Hall KS, Hui S (1998). The relationships between age, sex, and the incidence of dementia and Alzheimer disease: a meta-analysis. Arch Gen Psychiatry 55(9): 809-815.

11. Goldberg TE, Harvey PD, Wesnes KA, Snyder PJ, Schneider LS (2015). Practice effects due to serial cognitive assessment: 
Implications for preclinical Alzheimer's diseas erandomized controlled trials. Alzheimers Dement (Amst.) 1(1): 103-111. DOI: 10.1016/j.dadm.2014.11.003.

12. Holmerová I, Jurašková B, Zikmundová K, et al. (2007). Vybrané kapitoly z gerontológie. Praha: EV publicrelations, spol. s r. o.

13. Hort J, Rusina R, et al. (2007). Pamět' a její poruchy: pamět' z hlediska neurovědního a klinického. Praha: Maxdorf.

14. Iliffe S, Manthorpe J, Eden A (2003). Sooner or later? Issues in the early diagnosis of dementia in general practice: a qualitative study. Fam Pract 20(4): 376-381. DOI: 10.1093/fampra/ cmg407.

15. Kalvach Z, Zadák Z, Jirák R, Zavázalová $H$, Sucharda $P$, et al. (2004). Geriatrie a gerontologie. Praha: Grada.

16. Kalvach Z, Zadák Z, Jirák R, Zavázalová $H$, Holmerová $I$, Weber P, et al. (2008). Geriatrické syndrómy a geriatrický pacient. Praha: Grada.

17. Khan TK, Alkon DL (2015). Alzheimer's disease cerebrospinal fluid and neuroimaging biomarkers: diagnostic accuracy and relationship to drug efficacy. J Alzheimers Dis 46(4): 817-836. DOI: $10.3233 / J A D-150238$.

18. Lam B, Middleton LE, Masellis M, Stuss DT, Harry RD, Kiss A, Black SE (2013). Criterion and convergent validity of the Montreal cognitive assessment with screening and standardized neuropsychological testing. J Am Geriatr Soc 61(12): 21812185. DOI: $10.1111 /$ jgs.12541.

19. Lezak MD, Howieson DB, Loring DW, Fischer JS (2004). Neuropsychological Assessment. New York: Oxford University Press.

20. Lin JS, O'Connor E, Rossom RC, Perdue LA, Eckstrom E (2013). Screening for cognitive impairment in older adults: a systematic review for the U.S. Preventive Services Task Force. Ann Intern Med 159(9): 601-612. DOI: 10.7326/0003-4819-159-9201311050-00730.

21. Mangialasche F, Kivipelto M, Solomon A, Fratiglioni L (2012). Dementia prevention: current epidemiological evidence and future perspective. Alzheimers Res Ther 4(1): 6. DOI: 10.1186/ alzrt104.

22. Mauk KL (2013). Gerontological nursing: Competencies for care. Massachusetts: Jones and Bartlett Learning.

23. Miech RA, Breitner JC, Zandi PP, Khachaturian AS, Anthony JC, Mayer L (2002). Incidence of AD may decline in the early 90s for men, later for women: the Cache County study. Neurology 58(2): 209-218. DOI: 10.1212/WNL.58.2.209.

24. Mielke MM, Vemuri P, Rocca WA (2014). Clinical epidemiology of Alzheimer's disease: assessing sex and gender differences. Clin Epidemiol 6: 37-48. DOI: 10.2147/CLEP.S37929.

25. Mitchell SL, Kiely DK, Hamel MB (2004). Dying with advanced dementia in the nursing home. Arch Intern Med 164(3): 321-326. DOI: 10.1001/archinte.164.3.321.

26. Moss MS, Braunschweig H, Rubinstein RL (2002). Terminal care for nursing home residents with dementia. Alzheimer's Care Q 3(3): 233-246.

27. Nasreddine ZS, Phillips NA, Bédirian V, Charbonneau S, Whitehead V, Collin I, et al. (2005). The Montreal cognitive assessment, MoCA: A brief screening tool for mild cognitive impairment. J Am Geriatr Soc 53(4): 695-699. DOI: $10.1111 / j .1532-5415.2005 .53221 . x$.
28. Ondášiová M (2011). Kognitívne poruchy vo vyššom veku. Bratislava: Herba

29. Pinto T, Machado L, Bulgacov T, Rodrigues-Júnior A, Costa M, Ximenes R, Sougey E (2018). Is the Montreal cognitive assessment (MoCA) screening superior to the MiniMental State Examination (MMSE) in the detection of mild cognitive impairment (MCI) and Alzheimer's Disease (AD) in the elderly? Int Psychogeriatr 14: 1-14. DOI: 10.1017/ S1041610218001370.

30. Pokorná A et al. (2013). Ošetřovatelství v geriatrii. Hodnoticí nástroje. Praha: Grada.

31. Neuroimunologické centrum pre výskum Alzheimerovej choroby (2008). Príručka. Bratislava.

32. Reban J (2006). Montrealský kognitivní test (MoCA): přínos k diagnostice predemencí. Česká Geriatrická Revue 4: 224-229.

33. Shekelle PG, Maclean CH, Morton SC, Wenger NS (2001). Acove quality indicators. Ann Intern Med 135(8 Pt 2): 653-667.

34. Siqueira GS, Hagemann PM, Coelho DS, Santos FH, Bertolucci PH (2018). Can MoCA and MMSE be interchangeable cognitive screening tools? A systematic review. Gerontologist [Epub ahead of print]. DOI: 10.1093/geront/gny126.

35. Smith GE, Bondi MW (2013). Mild cognitive impairment and dementia: definitions, diagnosis, and treatment. New York: Oxford University Press.

36. Smolík P (1996). Duševní a behaviorální poruchy. Průvodce klasifikací, nástin nozologie, diagnostika. Praha: Maxrorf.

37. Solomon A, Kivipelto M, Soininen H (2013). Prevention of Alzheimer's disease: moving backward through the lifespan. J Alzheimers Dis 33(1): 465-469. DOI: 10.3233/JAD-2012129021.

38. Spencer RJ, Wendell CR, Giggey PP, Katzel LI, Lefkowitz DM Siegel EL, Waldstein SR (2013). Psychometric limitations of the Mini-Mental State Examination among non demented older adults: anevaluation of neurocognitive and magnetic resonance imaging correlates. Exp Aging Res 39(4): 382-397. DOI: 10.1080/0361073X.2013.808109.

39. Spering CC, Hobson V, Lucas JA, Menon CV, Hall JR, O'Bryant SE (2012). Diagnostic accuracy of the MMSE in detecting probable and possible Alzheimer's disease in ethnically diverse highly educated individuals: analysis of the NACC database. J Gerontol A Biol Med Sci 67(8): 890-896. DOI: $10.1093 /$ gerona/gls006.

40. Szaboó R (2006). 100 rokov od začiatku histórie Alzheimerovej choroby. Lekárske listy 22: 21.

41. Topinková E, Neurwith J (1995). Geriatria pre praktického lekára. Praha: Grada.

42. Turčáni P (2001). Alzheimerova choroba. Neuroscience. Bratislava: Pfizer, $27 \mathrm{p}$.

43. Vyhnálek M, Bartoš A, Dostál V, Franková V, Holmerová I, Laczó J, et al. (2011). Diagnostikujeme a léćíme demence správne a včas? Výsledky průzkumu ve světle nových doporučení. Neurol Praxi 12(5): 342-346.

44. WHO (2012). Dementia: a public health priority. United Kingdom: World Health Organization. 